\title{
介護予防プログラムと理学療法
}

\section{Physical Therapy and Programs of the Preventive Approach in the Long-Term Care Insurance}

島田 裕之1)

HIROYUKI SHIMADA, Ph.D., P.T. ${ }^{1)}$

${ }^{1)}$ Department for Prevention of Dependence on Long-term Care, Tokyo Metropolitan Institute of Gerontology: Sakae-cho, Itabashi-ku, Tokyo 173-0015, Japan. TEL +81 3-3964-3241 (2566)

Rigakuryoho Kagaku 19(2): 141-149, 2004. Received Mar. 11, 2004.

ABSTRACT: This paper reports on the role of the physical therapists in the preventive approach of the long-term care insurance introduced by Tokyo Metropolitan Institute of Gerontology. The preventive approach is a comprehensive approach in which the short-term program aims to improve geriatric syndrome and the long-term program includes involvement of administrative policy. It is thought physical therapists should play a leading role in the preventive approach of the long-term care insurance.

Key words: preventive approach, physical therapist, comprehensive program

要旨 : 東京都老人総合研究所で紹介している介護予防プログラムを概観し, 介護予防事業における理学療法士の役割 を述べた。介護予防事業は老年症候群の予防・改善を目的とした短期的なプログラムと, 行政施策を含めた長期的な 計画を組み合わせた包括的な取り組みが必要である。理学療法士は介護予防の中核的な役割を担うべき存在であると 考えられる。

キーワード : 介護予防, 理学療法士, 包括的プログラム

1）東京都老人総合研究所介護予防緊急対策室：東京都板橋区栄町35-2（テ173-0015）TEL 03-3964-3241（内線2566） 受付日 2004年3月11日 


\section{I.はじめに}

生活習慣病に対寸る検診制度や医療体制の確立，高水 準の公衆衛生，国民の疾病に対する意識の醸成などによ り, わが国の平均寿命は世界第一位を誇っている。今後 は健康寿命の延長が超高齢化社会を迎えるにあたり重要 な課題であり，そのカギとなるのが「介護予防」である と考えられる。介護予防に関する概念的な整理は行われ てきたが, 具体的な方法論を提示し, その方法を広く施 策に反映するまでには至っていなかった。そのため,こ れまでの介護予防事業の実施は, 担当寸る従事者の創意 工夫に頼らざるを得ない状況にあった。

本稿においては, 東京都老人総合研究所の研究成果を 基に開発された介護予防プログラムの概略を紹介し，各 プログラムにおける理学療法士の役割の重要性について 解説する。

\section{II. 健診プログラム}

介護予防事業の対象となる高齢者は，元気な健常高齢 者から要介護高齢者まで幅が広いが, 効果的かつ効率的
に事業展開を図るためには対象者を絞る必要がある。要 介護状態の主な要因は老年症候群であるため, 老年症候 群に陥る危険性の高い高齢者をスクリーニングし，介護 予防事業の対象者を選定するための健診システムが必要 となる。東京都老人総合研究所では老年症候群の危険性 を把握するための健診として「おたっしゃ21」という簡 便な検查を提案している。この検查は質問紙調查18項目 と3項目の運動機能検查（握力, 片足立ち, 歩行速度）に より構成され, 生活機能の低下, 転倒, 失禁, 低栄養, 軽度の痴呆などといった老年症候群のリスクの有無を判 定することが可能である（表1）。

ここで理学療法士が果たすべき役割としては, 運動機 能検查の実施である。握力, 片足立ち, 歩行速度の測定 は特殊なスキルは必要とされないが，対象者によっては 測定時に転倒することも想定される。事故を回避するた めに, 転倒に備えて検者の心構えや配置の指導, 転倒な どの危険がある対象者を検查する場合には，事前にス タッフに周知寸るなどの配慮が必要となる。多職種で健 診を行う場合には，理学療法士自身が検查を行うとは限 らないため, 検查遂行に際しての管理を積極的に担う必 要がある。

表1 おたっしや 21

目的

老年症候群（生活機能の低下，転倒，失禁，低栄養，軽度の痴呆など）のリスクを判定し，そ れらの早期発見・予防をする。また，介護予防事業・プログラムの効果についても判定する。

対象者

健診場所に来場可能な高齢者を対象とする。ただし，運動機能測定については中止基準に該当 した者は除外する（心血管系の疾患，血圧が収縮期 $180 \mathrm{mmHg}$ 拡張期 $100 \mathrm{mmHg}$ 以上など）。

効果

老年症候群のリスク判定により, 予防対策の必要な対象者が選定できる。オプションの検査を 付加することで介護予防プログラムの効果を評価できる。

健診内容・実施規模・所要時間・設備・機材（標準的な例）

健診内容 : 質問紙調査, 運動機能測定（筋力，バランス，歩行検查）

健診場所 : 対象者の来場が容易で, $150 \mathrm{~m}^{2}$ 以上の会場が望ましい

健診人数: 1 日あたり 100 名程度

検者数 : 健診全体で 5 名以上

所要時間 : 1 名につき 30 分程度

必要機材: 血圧計, 身長計, 体重計, 握力計, ストップウォッチ, 質問紙調査用紙

プログラムに関わるスタッフ（小規模実施の場合）

医師または保健師 1 名 : 健診の実施 (問診, 血圧測定), 緊急時対応

その他の専門職 3 名 : 質問紙調査, 運動機能測定

特に指定なし 1 名：受付，その他

健診の特徵

一般の健康診査と異なり, 老年症候群のリスク判定が可能であり, 介護予防プログラムの効果 を検証できる。 


\section{III. 身体機能向上を目的としたプログラム}

1. 老研式転倒予防プログラム

高齢者の転倒事故は大腿骨頸部骨折などの重篤な疾病 を惹起する。また転倒後症候群と呼ばれる活動性の低下 を後発させ, 要介護状態となる要因の 1 つして広く認識 されており，介護予防事業の中心的課題となっている。 しかし実際に事業化されている転倒予防教室は, 単発の 講演会のみや, 転倒の危険因子を考慮していない体操教 室であったりする。

老研式転倒予防プログラムは, 転倒の危険性が高いと 判断された高齢者に対し, 気軽に実践可能な軽・中強度 の運動プログラムを提供し, 転倒予防意識を高め, 活動 的な生活習慣を獲得することを目指している。プログラ ムの実施に際しては, 対象者の健康状態や身体機能水準
を詳細に把握した上でプログラムを適用し，施設招聘と 家庭内自主練習プログラムを併用して, 運動の習慣化が 図れるよう計画されている（表2）。

このプログラムにおいて理学療法士に期待される役割 は, 対象者個人の機能状態を把握し, 最適なプログラム 内容を適用することである。必要があれば理学療法評価 を行い，安全に運動ができるよう支援する。また，運動 継続のために実施するセルフモニタリング記録をみて, 運動実施を促すカウンセリング技能も求められる。

2. 自己管理型筋力増強プログラム

高齢者の介護予防にとって高齢者の運動機能を維持・ 向上させるための効果的な運動方法を提示し, その効果 を維持するための健康行動獲得へ向けた方略を確立する ことは急務の課題である。

表2 老研式転倒予防プログラム

目的

転倒の危険性が高い高齢者の転倒危険因子を改善し，転倒率の低下を目指す。 対象者

1. 要介護認定にて自立, または要支援と判定された者

2. 転倒経験を有する者

3. 転倒恐怖感を有する者

4. その他の虚弱高齢者 (膝伸展筋力が $20.0 \mathrm{~kg}$ 以下の人)

効果

1. 転倒の危険因子である筋力, バランス能力, 歩行能力が改善する

2. 転倒率が低下する

実施規模・プログラム内容・設備（標準的な例 $)$

参加人数 : 10 名程度

指導者数: 4 名

指導方法

(1)会場指導 : 2 週に 1 回・全 10 回（約 6 か月）

(2) 家庭用運動プログラムの活用

指導時間 : 1 回 90 分

設備 : $80 \mathrm{~m}^{2}$ 以上の部屋，ストレッチマット，バランスパッド，セラバンドなど

プログラムに関わるスタッフ

医師または保健師 1 名 : エントリー判定・健康管理

理学療法士 1 名 : 理学療法評価・痛みの管理

運動指導員 2 名 : 運動プログラムの立案と指導

プログラムの特徵

1. 転倒の危険性が高いと判断された高齢者に対し, 気軽に実践可能な軽・中強度の運動プロ グラムを提供する

2. 対象者の健康状態や身体機能水準を把握した上で，プログラムを適用する

3. 活動的な生活習慣の獲得を目指寸

4. 転倒予防運動の習慣化を目指し, 家庭用運動プログラムを提供する 
自己管理型筋力増強プログラムは，高齢者が自身の健 康を考えて,「運動」を通した健康増進（介護予防）活動 を高齢者が主体的に実践することをコンセプトに開発さ れている。プログラムの内容は, 運動の仕組みと筋力増 強の方法を学習する教育プログラムと, 特別な運動機器 は使わずに, 自宅でも容易に遂行可能な運動プログラム から構成されている（表3）。

このプログラムは理学療法士の視点から計画されてお り, 基礎的な解剖学や運動学的知識が要求されるため, 理学療法士が中心となって事業を展開していくことが望 ましい。病院で行う理学療法と照らし合わせると, 退院 を控えた患者にホームプログラムを指導していく過程に 似た手順であるといえる。

3. 高齢者筋力向上トレーニング

平成15年度に介護予防・地域支え合い事業の新規メ ニューとして採用された高齢者筋力向上トレーニング は，ウェイト・トレーニングマシンを用いた高負荷筋力 トレーニングを実施するプログラムである。

このプログラムは医師, 保健師, 理学療法士, 運動指
導員が共同して実施する学際的なプログラムであり，筋 カトレーニングと機能的トレーニングを組み合わせた包 括的なプログラムとなっている（表4）。

この中で理学療法士は, 高負荷筋力トレーニングを安 全に実施できるように, 痛みの管理や理学療法といった 個別的な対応をする役割として位置づけられている。そ のため他職種にない理学療法士の専門性が要求され, 代 替のきかない責務を負うことになる。

\section{IV. 知的機能向上を目的としたプログラム}

痴呆予備群といわれるAge Associated Cognitive Decline (AACD) やMild Cognitive Impairment（MCI）は地域高齢 者全体の 20 ～27\%を占めることが欧州の研究で明らかに され，そのなかの約 $30 \%$ の高齢者が3年以内に痴呆になる といわれている。このように近年, 非常に多くの高齢者 が痴呆の危険性を潜在的に有していることが明らかに なった。また, 分子レベルでのアルツハイマー病の病態 が解明されるようになり, アセチルコリン補充療法と いった薬物療法も可能となった。しかし, その効果には

表3 自己管理型筋力増強プログラム

目的

高齢者が運動の仕組みとその効用を理解し, 健康な身体づくりのための方略を学習し, それを実践すること。 対象者

1. 日常生活動作は自立しているが，手段的日常生活の自立に支障を来たしているか，もしくは不安を感じて いる高齢者

2. 支えを利用して片脚立位保持可能者であること

効果

1. 高齢者が自身の身体や運動の仕組みを理解し，健康づくりを自ら実践できる

2. 筋力やバランス能力が向上し, 日常生活上の諸活動の困難さが減少する

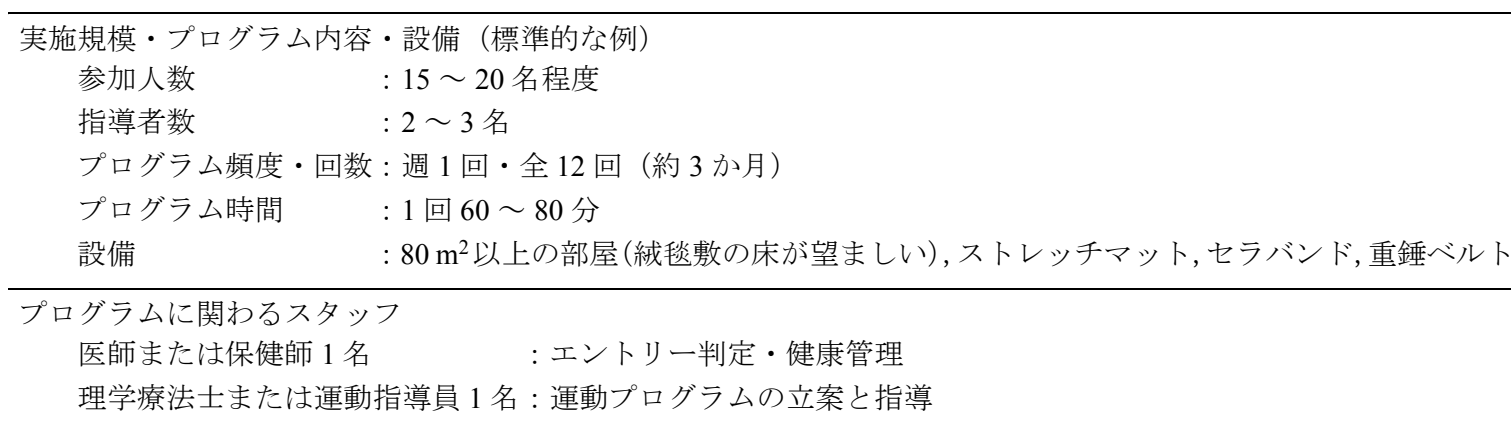

プログラムの特徴

1. 運動の仕組みと筋力増強の方法を学習し, それを実践する

2. 対象は虚弱から健康な高齢者

3. 特別な機械は使わずに，自らの体重を利用した運動を主とする

4. 高齢者が独力で実施可能な運動プログラムを提供する 
限界があり，今後の根治的治療法の開発が待たれている。

一方で, 社会科学領域においても, 認知的活動や身体 活動と高齢期における認知機能の低下との関係が, 長期 縦断研究によって明らかにされるようになってきた ${ }^{1,2)}$ 。 たとえば趣味，歩行習慣，友人宅への訪問，ボランティ ア活動，カードゲームなどの活動を積極的に行っている 高齢者はアルツハイマー病になる危険性が約40\%減少す ると報告されている3)。また，近年の研究では，ゲーム， 読書, 音楽演奏といった認知的活動では痴呆の危険性を 抑制できる可能性があるが，身体活動とは関連が認めら れなかったとする報告もある4)。いずれにしても, 痴呆や 認知機能低下と活動との関連性についての研究は限られ ており, 今後の成果を待たなければならない。さらに, 活動と痴呆との因果関係を検討するためには, 介入研究 が実施されなければならないが, 系統的に計画された研 究は見当たらない。

東京都老人総合研究所痴呆介入研究グループでは, 初 期の痴呆でよく観察されるエピソード記憶障害, 注意分 割機能の低下，計画力の低下に着目したプログラムを開
発し, 地域で実践研究を進めている。このプログラムは 料理, 旅行, 園芸, パソコンや運動を組み合わせてグルー プワークを行う。これらの活動の管理, 運営は事前に養 成研修を終えた地域の人材が担い，活動が地域に根ざす ことを視野に置くところに特徵がある（表5）。

痴呆予防というと理学療法士と関係が薄いと思われが ちだが，身体活動が痴呆発生の抑制と関連するとされて いる5,6)。また, 認知的活動を行うにしても, それらの活 動の基礎となる移動能力が低下寸れば活動範囲が狭小化 し, 認知的活動量が減少するのは自明である。そのため, 運動指導を専門とする理学療法士が痴呆予防事業にも参 画する必要性は十分にあると考えられる。

\section{V. 生活上の問題の解決を目的としたプログラム}

\section{1. 尿失禁予防プログラム}

地域に在住する女性高齢者の 15 ～45\%が尿失禁を経験 し，重度の尿失禁を有する者は10\%程度といわれ7)，この うち, 週1回以上の失禁を有する者の割合は高齢になるほ

表4 高齢者筋力向上トレーニング

目的

虚弱高齢者や要介護高齢者の身体機能を高め, 要介護状態に陥ることを防ぐ。

対象者

1. 要介護認定にて自立, 要支援, 要介護 $1 \cdot 2$ と判定された者

2. その他の虚弱高齢者（最大歩行速度が $80 \mathrm{~m} /$ 分未満の者など）

効果

1. 要介護状態に陥る時期を遅らせる

2. 要介護状態になった場合の程度を軽減する

3. 介護サービス量を軽減する

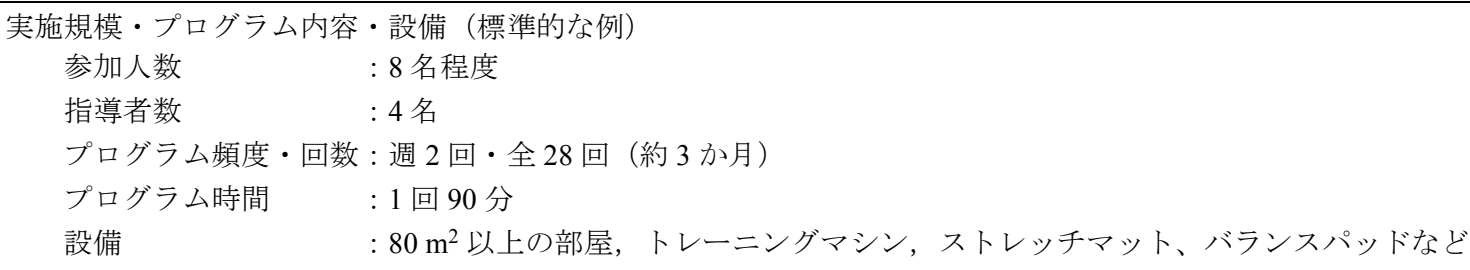

プログラムに関わるスタッフ

医師または保健師 1 名：エントリー判定・健康管理

理学療法士 1 名 : 理学療法評価・痛みの管理・個別プログラム作成

運動指導員 2 名 : 運動プログラムの立案と実践

プログラムの特徵

1. 積極的なトレーニングで介護率を減少させる

2. 対象は虚弱高齢者と要介護認定で自立, 要支援, 要介護 $1 \cdot 2$ と判定された高齢者とする

3. 健康増進施設と類似したトレーニングマシンを使用する

4. 短期間に機能向上を目的とした包括的なプログラムを提供する 
ど上昇することが明らかとされている8)。尿失禁によって 高齢者は身体的, 心理的, 社会的な悪影響を被り, 重大 な機能低下を起こす可能性がある。身体的には感染症, 皮膚の損傷, 活動性の低下が生じ, 心理的には自己嫌悪 感, 恐怖感などからうつ状態に陷る可能性がある99。ま た, 社会的には社会参加の制約, 経済的負担の増大など が考えられる。

失禁予防を目的とした介入方法としては手術療法, 薬 物療法, 教育・トレーニングが行われている。手術療法 は中等度以上の腹圧性尿失禁に対して行われ 90 ～95\%の 対象者が完治する高い治療成績を有する。薬物療法では, 切迫性尿失禁に対して抗コリン薬や平滑筋驰緩薬が用い られ, 腹圧性尿失禁では $\alpha$ 刺激薬と三環系抗うつ薬が処 方される。また，近年では閉経後の女性に対するエスト ロゲンを補充するホルモン補充療法が試みられている。 教育・トレーニングに関しては, 排尿に関する正しい知 識の講習や排尿記録, 膀胱トレーニング, 骨盤底筋群の 強化, 肥満の改善, 失禁に対するサニタリー用品の紹介,
屋内環境の調整が実施される。

東京都老人総合研究所で紹介する尿失禁予防プログラ ムは, 教育・トレーニングプログラムであり, 医学的教 育・相談, 骨盤底筋卜レーニング，栄養指導を包括的に 提供寸る。また，トレーニングによって効果の認められ ない対象者を医療機関へ紹介寸る点が特徴として挙げら れる(表6)。

このプログラムで理学療法士は骨盤底筋トレーニング に関与する。骨盤底筋群に対するアプローチの経験を持 たない理学療法士も多いと思われるが，欧米においては 高齢女性あるいは, 前立腺切除後の尿失禁に対する理学 療法アプローチが盛んに行われてきた経緯から, 効果に 対する知見の集積や，トレーニング方法に関する書籍も 多数出版されている。また, 介護予防事業だけでなく, 病院や施設においても尿失禁は重大かつ, 頻発する問題 であるため，わが国でも研究成果が散見される。今後は この分野における理学療法がますます発展し, 日本版の 効果的トレーニング法の確立を期待する。

表5 地域型痴呆予防プログラム

目的

認知機能を刺激するパソコン, 園芸, 旅行, 料理などの知的活動プログラムを実施することで認知機能 を維持し，運動習慣化と合わせて，痴呆発症を抑制・遅延化する。

対象者

地域高齢者の約 $2 \sim 3$ 割いると考えられる痴呆リスク群の高齢者を含めた，健康な高齢者。 効果

1.グループ活動を通して, 痴呆の発症を遅らせる

2. 痴呆予防プログラムの活動を通して, 地域づくりができる

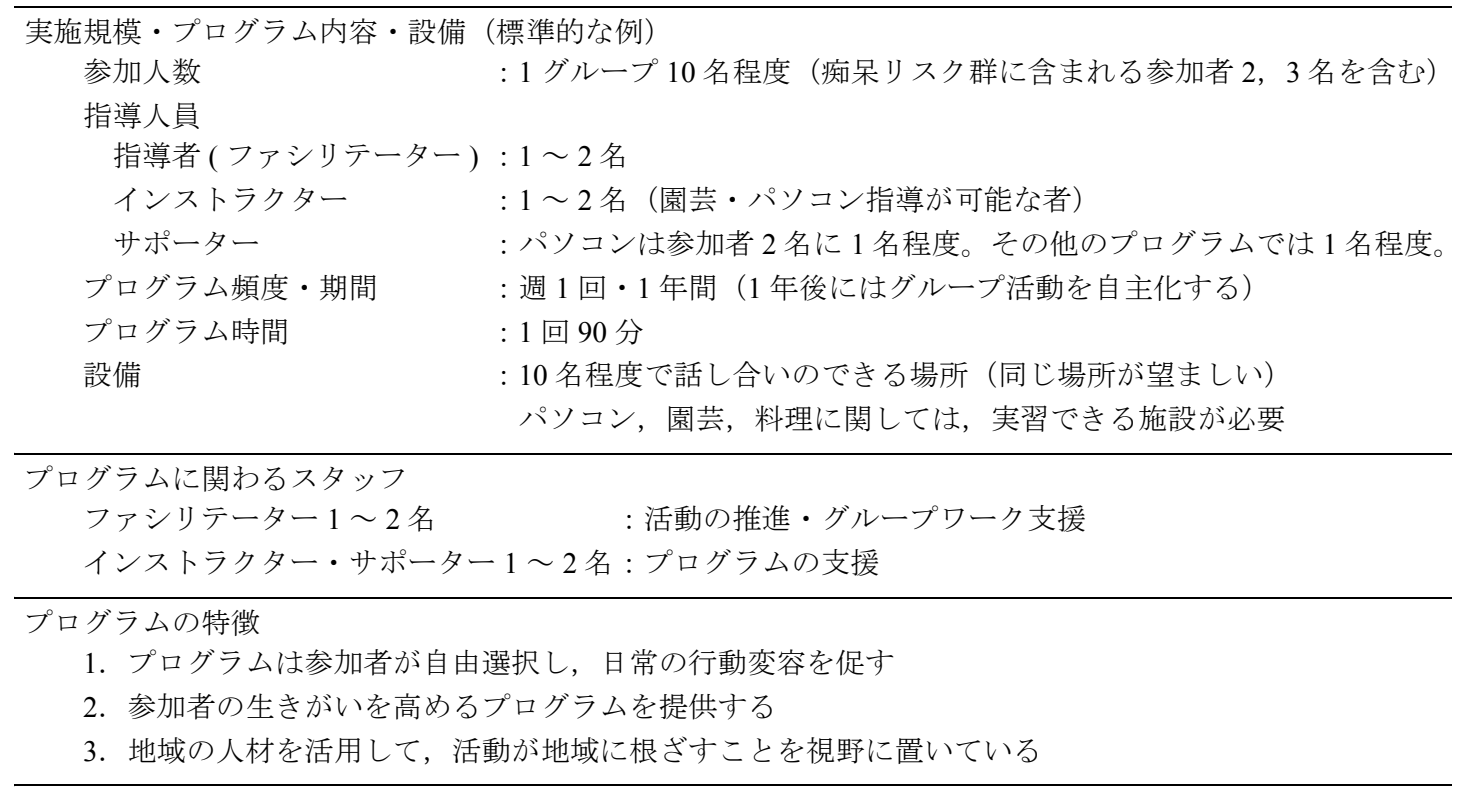


表6 尿失禁予防プログラム

目的

骨盤底筋，および腹部，下肢筋力を向上するためのトレーニングを実施することにより，尿失禁症状の予防・改善を 図り，社会活動の制限を予防する。外科的，内科的治療が必要な者をスクリーニングする。

対象者

1. 尿失禁の経験を有する者

2. 尿失禁予防のために骨盤底筋トレーニング方法の習得を希望する者

効果

1. 尿失禁の症状が改善し, 日常生活上の支障がなくなる

2. 活動範囲の拡大に伴い社会性が増し，QOL が向上する

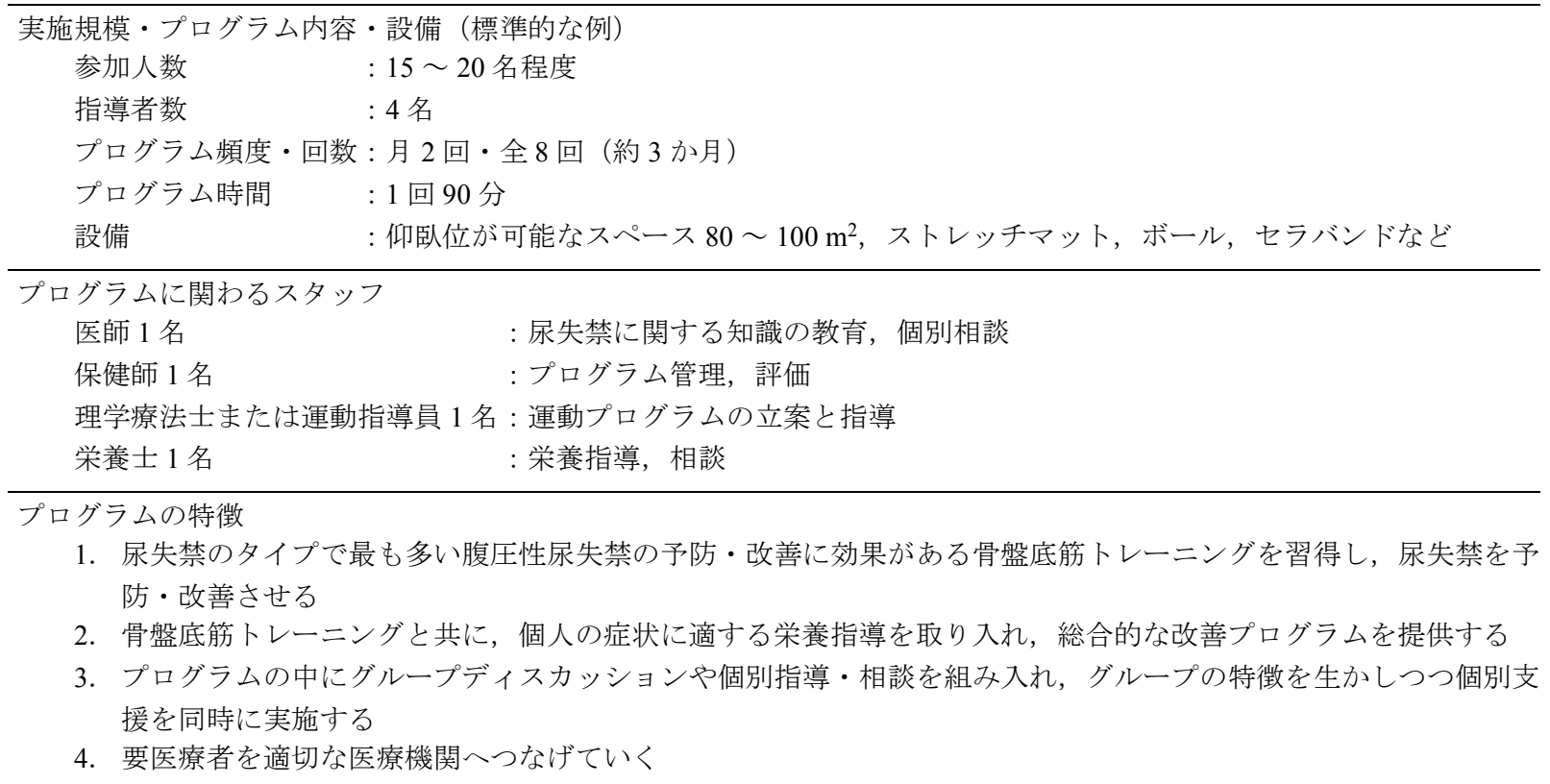

2. 熊谷式低栄養予防プログラム

生活習慣病予防のために, 低脂質, 低カロリー食が推 奨されるが，高齢期には低栄養状態に陥ることにも注意 を払う必要がある。高齢者は食嗜好が低たんぱく質，低 脂質に偏りがちで，食物摂取量が減少している場合が多 く, 低栄養状態になる潜在的要素を抱えている。低栄養 は筋力低下やうつに関与し, 高需者の機能低下を助長す る要因である。

熊谷式低栄養予防プログラムは，食に関する正しい知 識を学習し, 食行動の変容を促すプログラムであり, 高 齢者に不足しがちな動物性たんぱく質の摂取を促進する (表7)。

理学療法士が直接このプログラムに参加することは少 ないが, 低栄養予防の目的のひとつは体力の維持, 向上 であるため, 運動プログラムと連携することで効果を得 ることが可能となる。逆にいえば，運動プログラムを実
施する際も，対象者の栄養状態を把握し，低栄養が疑わ れる場合には適切に対処することが要求される。

\section{VI. 介護予防事業効果の持続を目的とした施策}

紹介した介護予防プログラムの実施期間は，ほとんど が3〜6か月間の短期プログラムである。これは, 介護予 防事業が自立を支援する目的として行われるため，長期 にわたるサービスの提供により，対象者の依存度を高め てしまう可能性を回避するためである。また, 介護予防 の対象となりえる人数は膨大であり, より多くの人に サービスを提供するためでもある。しかし，プログラム 実施後に生活を元に戻してしまえば，その効果はすぐに 消失してしまう。効果を持続するためには高齢者本人へ の支援と，地域環境を整えて活動しやすい街づくりをす ることが必要となる（表8）。 
表7 熊谷式低栄養予防プログラム

目的

低栄養状態およびその危険性が高い自立高齢者を対象として，要介護状態を予防するためのからだの栄養状態 の維持・増進を目指す。

対象者

1. 血清アルブミン $3.8 \mathrm{~g} / \mathrm{dl}$ 以下の低栄養状態の高齢者

2. 血清アルブミン $3.8 \mathrm{~g} / \mathrm{dl}$ 超であるが将来低栄養になるリスクを抱えている高齢者

3. 低栄養リスクを有する高齢者

効果

1. 低栄養状態を改善・予防する

2. 低栄養から生じる体力低下を予防する

実施規模・プログラム内容・設備（標準的な例）

参加人数 $\quad: 30 \sim 40$ 名程度

指導者 : $1 \sim 3$ 名（管理栄養士，栄養士，高齢者給食サービス事業従事者，地域食生活改善活 動ボランティア, 保健師など）

プログラム頻度・回数 : 評価や講義の終了後, 月に 1 回程度の学習会を定期的に開催（6か月以上）

プログラムの時間 : : 2 時間程度

設備 : 調理器具のある部屋

プログラムに関わるスタッフ

管理栄養士・栄養士 1 名 : エントリー判定・教室運営

高齢者給食サービス事業従事者, 地域食生活改善活動ボランティア, 保健師 1 ～ 2 名: プログラムの作成と実践

プログラムの特徵

1. 食生活の実態を詳細に把握し，現状を評価する

2. 活動状態や体力の状態を考慮したプログラム

3. 食事のみでなく活動推進を含んだ包括的プログラム

4. 動物性たんぱく質摂取を促すプログラム

近年, 多くの理学療法士が行政職に就いており, 介護 予防を目指した地域づくりは，これらの理学療法士が企 画段階から関与することで，より有機的なものになると 期待される。また, 地域づくりの企画に参画できない理 学療法士の代表としての責務もあり, その役割の重要性 は高いといえる。

\section{VII. おわりに}

介護予防とリハビリテーションは，ともに対象者が自 立して，いきいきと生活することの支援が目的である。 これを達成するためには, 地域における病院, 福祉施設, 保健機関の連携が必須である。病院で働く理学療法士は, 転院を促すのか, それとも介護保険サービスにつなげる のか，あるいは介護予防サービスを紹介すべきかを検討 する必要がある。まずは, 多くの理学療法士が介護予防 事業の内容を知り, 自分もその一役を担う立場にあるこ とを再認識することが重要であると考えられる。
表8 高齢者の行動変容や地域環境づくり

1. 行動変容の支援 短期プログラムの効果を継続するため, 高齢者の行 動変容を促す支援

2. 行政職員や高齢者を対象とした研修会・講演 介護予防の重要性や方法論の普及啓発

3. ボランティアの育成・グループの形成 ボランティアを養成し地域に受け皿を作る

4. 地域連携促進の支援 介護予防に関わる行政, 保健, 福祉の連携強化を支援

5. データ分析・先進事業の紹介 現在行っている事業の妥当性を検証, 成功モデルを 提示

\section{引用文献}

1) Hultsch DF, Hertzog C, Small BJ, et al.: Use it or lose it; engaged lifestyle as a buffer of cognitive decline in aging? Psychol Aging, 
1999, 14: 245-263.

2) Laurin D, Verreault R, Lindsay J, et al.: Physical activity and risk of cognitive impairment and dementia in elderly persons. Arch Neurol, 2001, 58: 498-504.

3) Scarmeas N, Levy G, Tang MX, et al.: Influence of leisure activity on the incidence of Alzheimer's disease. Neurology, 2001, 57: 2236-2242.

4) Verghese J, Lipton RB, Katz MJ, et al.: Leisure activities and the risk of dementia in the elderly. N Eng J Med, 2003, 348: 25082516.

5) Lindsay J, Laurin D, Verreault R, et al.: Risk factors for Alzheimer's disease: a prospective analysis from the Canadian Study of Health and Aging. Am J Epidemiol, 2002, 156: 445-453.
6) Yoshitake T, Kiyohara Y, Kato I, et al.: Incidence and risk factors of vascular dementia and Alzheimer's disease in a defined elderly Japanese population: the Hisayama Study. Neurology, 1995, 45: 1161-1168.

7) Hunskaar S, Arnold EP, Burgio K, et al.: Epidemiology and Natural History of Urinary Incontinence. Int Urogynecol J, 2000, 11: 301-319.

8) Milsom I: The prevalence of urinary incontinence. Acta Obstet Gynecol Scand, 2000, 79: 1056-1059.

9) Bogner HR, Gallo JJ, Sammel MD, et al.: Urinary incontinence and psychological distress in community-dwelling older adults. $\mathrm{J}$ Am Geriatr Soc, 2002, 50: 489-95. 